\title{
Characterising terrestrial influences on Antarctic air masses using Radon-222 measurements at King George Island
}

\author{
S. D. Chambers ${ }^{1}$, S.-B. Hong ${ }^{2}$, A. G. Williams ${ }^{1}$, J. Crawford ${ }^{1}$, A. D. Griffiths ${ }^{1}$, and S.-J. Park ${ }^{2}$ \\ ${ }^{1}$ Australian Nuclear Science and Technology Organisation, Locked Bag 2001, Kirrawee DC NSW 2232, Australia \\ ${ }^{2}$ Korea Polar Research Institute, 26 Songdomirae-ro, Yeonsu-gu, Incheon, 406-840, Korea \\ Correspondence to: S. D. Chambers (szc@ansto.gov.au)
}

Received: 1 April 2014 - Published in Atmos. Chem. Phys. Discuss.: 8 May 2014

Revised: 7 July 2014 - Accepted: 22 August 2014 - Published: 18 September 2014

\begin{abstract}
We report on one year of high-precision direct hourly radon observations at King Sejong Station (King George Island) beginning in February 2013. Findings are compared with historic and ongoing radon measurements from other Antarctic sites. Monthly median concentrations reduced from $72 \mathrm{mBq} \mathrm{m}^{-3}$ in late-summer to $44 \mathrm{mBq} \mathrm{m}^{-3}$ in late winter and early spring. Monthly 10th percentiles, ranging from 29 to $49 \mathrm{mBq} \mathrm{m}^{-3}$, were typical of oceanic baseline values. Diurnal cycles were rarely evident and local influences were minor, consistent with regional radon flux estimates one tenth of the global average for ice-free land. The predominant fetch region for terrestrially influenced air masses was South America $\left(47-53^{\circ} \mathrm{S}\right)$, with minor influences also attributed to aged Australian air masses and local sources. Plume dilution factors of 2.8-4.0 were estimated for the most terrestrially influenced (South American) air masses, and a seasonal cycle in terrestrial influence on tropospheric air descending at the pole was identified and characterised.
\end{abstract}

\section{Introduction}

Due to the comparatively low land fraction, population density, and industrial activity in the Southern Hemisphere, Antarctic air masses are the least anthropogenically influenced in the global atmosphere (e.g. Jones et al., 2008; Helmig et al., 2007; Illic et al., 2005; Wolff et al., 1998; Pereira, 1990), and interpretation of trace impurities in Antarctic ice cores has become a popular window through which to view past global climate. To do this, however, requires a solid understanding of the transport and fate of trace elements to this region. Furthermore, since the climate and ecology of Antarctica is highly sensitive to anthropogenic influence (e.g. Steig and Orsi, 2013; Heffernan, 2012; Pereira et al., 2006), there is growing interest in quantifying the magnitude and source regions of pollutants affecting this pristine region (e.g. Jones et al., 2008; Pereira et al., 2004; Jacobi et al., 2000; Berresheim and Eisele, 1998). In turn, anthropogenically driven changes to Antarctic climate and ecosystems have the potential to feedback to the global climate system, due to the significant role that Antarctica plays in largescale atmospheric and oceanic circulation patterns.

In addition to the direct transport of pollutants in the atmospheric boundary layer, measured concentrations of trace species in Antarctica are influenced by both local sources and a variety of in situ natural chemical processes that have yet to be completely characterised, driven by the extreme seasonal contrasts in sunlight and temperature (e.g. Crawford et al., 2001; Davis et al., 2001, 2004; Oncley et al. 2004; Jones et al., 2008). Furthermore, the precise role that global circulation patterns play in the seasonal cycles of some trace species in Antarctica continues to challenge the global modelling community (Zhang et al., 2011, 2008; Josse et al., 2004; Taguchi et al., 2002; Heinmann et al., 1990).

Continuous measurements of a terrestrial tracer with uncomplicated source/sink mechanisms, such as Radon-222 (radon), employed in conjunction with back-trajectory analyses and meteorological observations, provide an unambiguous means of distinguishing boundary layer air masses containing a significant remote terrestrial influence (potentially polluted) from those which have been influenced only by natural oceanic and local processes. Together, they also provide a convenient means by which to estimate the dilution of ter- 
Table 1. Summary of previous radon observations in the Antarctic.

\begin{tabular}{|c|c|c|c|}
\hline Study & Technique & Measurement resolution & Location/duration \\
\hline Lockhart (1960) & Indirect (by progeny) & Daily (16:00-16:00 LST) & $\begin{array}{l}\text { Little America V, Apr } 1956 \text { to Oct } 1958 . \\
\text { South Pole, Feb } 1959 \text { to Apr } 1960 .\end{array}$ \\
\hline Lockhart et al. (1966) & Indirect (by progeny) & Daily & $\begin{array}{l}\text { Little America, Apr } 1956 \text { to Oct } 1958 . \\
\text { South Pole } 1959 \text { to } 1963 \text {. } \\
\text { Reports mean radon from other Antarctic sites: } 8 \text { - } \\
163 \mathrm{mBq} \mathrm{m}^{-3} \text {. }\end{array}$ \\
\hline Lambert et al. (1970) & Indirect (by progeny) & 2 hourly & Dumont d'Urville 1967 - ongoing. \\
\hline Wilkniss et al. (1974) & Indirect (by progeny) & 2 hourly & $\begin{array}{l}40 \text { day ocean cruise to McMurdo, Antarctica Nov- } \\
\text { Dec } 1972 .\end{array}$ \\
\hline Maenhaut et al. (1979) & Indirect (by progeny) & Once daily 09:00-10:00 LST & South Pole, two summers (1973-74 and 1974-5). \\
\hline Polian et al. (1986) & Indirect (by progeny) & 2 hourly & $\begin{array}{l}\text { Dumont d'Urville 1960-1975; also report Maw- } \\
\text { son averages. }\end{array}$ \\
\hline Heimann et al. (1990) & Indirect (by progeny) & see Polian et al. (1986). & Dumont d'Urville. \\
\hline $\begin{array}{l}\text { Pereira (1990); } \\
\text { Pereira et al. (2004); } \\
\text { Pereira et al. (2006) }\end{array}$ & Direct (electrostatic deposition) & Daily and 2 hourly & Ferraz station, 1986 - ongoing. \\
\hline Wyputta (1997) & Indirect (by progeny) & Daily & Georg-von-Neumayer station, 1984-1989. \\
\hline Gros et al. (1998) & Indirect (by progeny) & $\begin{array}{l}1-2 \text { obs. day }{ }^{-1} \\
2 \mathrm{~h} \text { integration }\end{array}$ & Ocean cruise $\left(44-77^{\circ} \mathrm{S}\right)$, summer, 1993. \\
\hline Ui et al. (1998) & Direct (electrostatic deposition) & Hourly & Syowa Station, 5 months. \\
\hline Whittlestone and Zahorowski (2000) & Direct (two filter) & Hourly & Mawson station, Jan-1999 to Aug-2000. \\
\hline Taguchi et al. (2002) & Indirect (by progeny) & 1-2 hourly & Dumont d'Urville, $1967-1981$. \\
\hline Tositti et al. (2002) & Direct (electrostatic deposition) & Hourly & $\begin{array}{l}\text { Terra Nova Bay, Ferraz Station; } 3 \text { summers, 1995- } \\
1998 .\end{array}$ \\
\hline Josse et al. (2004) & Indirect (via progeny) & see Polian et al. (1986) & Dumont d'Urville. \\
\hline Ilic et al. (2005) & Various methods & & $\begin{array}{l}\text { Various observations from Academician Vernad- } \\
\text { sky Station (a review) }\end{array}$ \\
\hline Zhang et al. (2008) & Indirect (by progeny) & see Heimann et al. (1990) & Dumont d'Urville, Dec-1978 to Nov-1979. \\
\hline Zhang et al. (2011) & $\begin{array}{l}\text { Direct (two filter) at Mawson, } \\
\text { others indirect (by progeny) }\end{array}$ & $\begin{array}{l}\text { see Wittlestone and Zahorowski (2000); } \\
\text { and Heimann et al. (1990) }\end{array}$ & Mawson, Dumont d'Urville, 1 year. \\
\hline Taguchi et al. (2013) & Direct (electrostatic deposition) & $10 \mathrm{~min}$ & Ocean cruise to $69^{\circ} \mathrm{S}, 2$ summers (2004-2005). \\
\hline Weller et al. (2013) & Indirect (by progeny) & 3 hourly & Georg-von-Neumayer station, 1995-2011. \\
\hline
\end{tabular}

restrially influenced air masses en route to the point of measurement. With such tools, the sources of precursor species in the Antarctic atmosphere can be better characterised, and deposition processes better understood.

Atmospheric radon measurements have been reported for Antarctic regions for over 5 decades (Table 1). "Indirect" measurements, based on the collection and counting of radon progeny, have been the most common, but require an assumption of equilibrium between radon gas and its aerosol progeny. This assumption is generally considered to be valid for sites that are a significant distance from the radon's terrestrial source, if weather conditions are fairly calm en route, but is likely to fail for precipitating air masses and severe seastates. Of the "direct" techniques, electrostatic deposition has been the most common. However, for short integration times (e.g. $1 \mathrm{~h}$ ), the detection limit can be high $\left(160-200 \mathrm{mBq} \mathrm{m}^{-3}\right.$; Wada et al., 2010). The direct two-filter dual-flow-loop technique reported in this study is unique with regard to its broad applicability to weather/fetch conditions and its very low detection limit at hourly temporal resolution (see Sect. 2.2).

In February 2013, an existing aerosol and trace-gas monitoring program of the Korea Polar Research Institute (KOPRI) at King Sejong Station was enhanced by the addition of continuous hourly atmospheric radon observations. While numerous studies have already used radon to assist with the interpretation of trace species transported to, or produced within, the Antarctic atmosphere (Gros et al., 1998; Winkler,
1992; Murphey and Hogan, 1992; Wyputta, 1997; Pereira et al., 2004, 2006), few of the published data sets have provided continuous, direct (i.e. not via progeny), long-term, highsensitivity radon observations, with hourly temporal resolution.

The aims of this study are (i) to provide an overview of the King Sejong Station radon program, (ii) to characterise the temporal variability observed in the first year of operation, (iii) to compare our findings with existing Antarctic radon observations, (iv) to characterise the fetch regions of the most terrestrially influenced air masses at King Sejong Station and (v) to demonstrate the utility of radon for elucidating transport processes and large-scale circulation characteristics in this important region.

\section{Methods}

\subsection{Site and surrounds}

The KOPRI has operated at King Sejong station $\left(62.217^{\circ} \mathrm{S}\right.$, $58.783^{\circ} \mathrm{W}$; Figs. 1 and 2) since 1988 (http://gaw.empa.ch/ gawsis/reports.asp?StationID=2076202714). The station became part of the World Meteorological Organisation (WMO) network in 1989 (index no. 89251), and has operated as a regional WMO Global Atmosphere Watch (GAW) station since October 2010 (GAW ID “KSG”). King Sejong station 


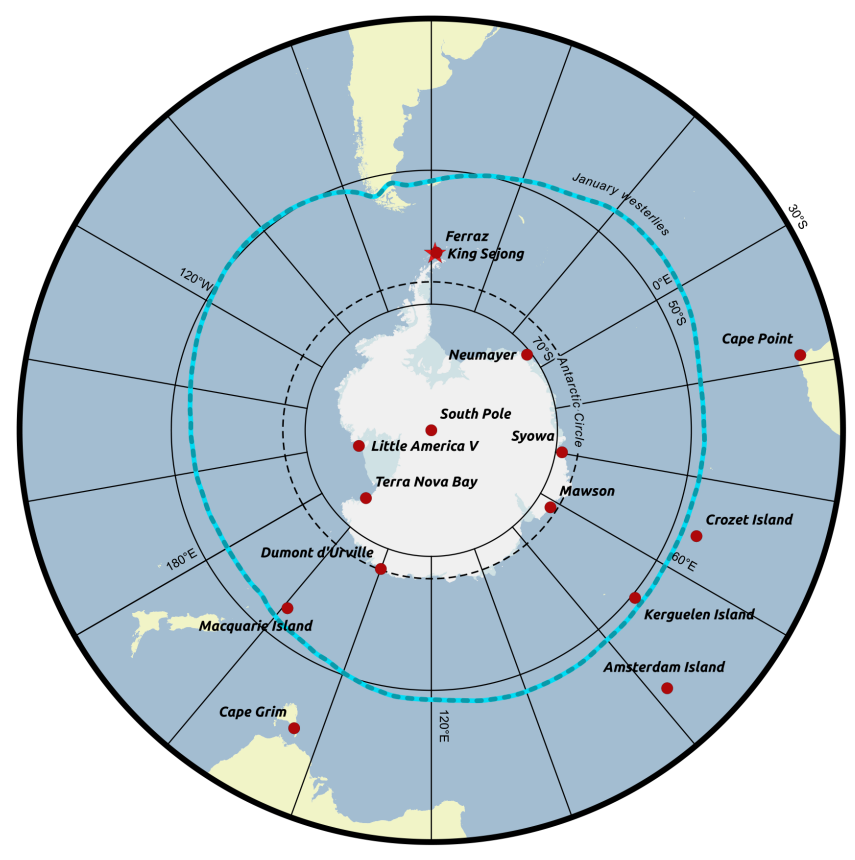

Figure 1. Overview of historic and current atmospheric radon measurement sites in Antarctic and sub-Antarctic regions, including King Sejong station, Antarctic Peninsula. Mean track of summer westerly winds indicated in blue.

(KSG) lies off the tip of the Antarctic Peninsula on Baton Peninsula, King George Island (Fig. 1 and 2a), and has a relatively undisturbed oceanic fetch from the west through north-northwest. The spit of land west of the station separating KSG from the Southern Ocean (Fig. 2a) is $2-4 \mathrm{~km}$ wide and $<200 \mathrm{~m}$ above sea level (a.s.l.).

Hourly climate data for the study (e.g. Fig. 3) were sourced from a nearby automatic meteorological observation system (AMOS-1; Fig. 2b) on a $10 \mathrm{~m}$ weather tower. The available observations include: air temperature $\left({ }^{\circ} \mathrm{C}\right)$, dew point temperature $\left({ }^{\circ} \mathrm{C}\right)$, relative humidity $(\%)$, pressure $(\mathrm{hPa})$, wind speed $\left(\mathrm{m} \mathrm{s}^{-1}\right)$, wind direction $\left(^{\circ}\right)$, solar radiation $\left(\mathrm{W} \mathrm{m}^{-2}\right)$, ultra-violet radiation $\left(\mathrm{W} \mathrm{m}^{-2}\right)$ and surface temperature $\left({ }^{\circ} \mathrm{C}\right)$ (see also Lee et al., 2002). Measurements of atmospheric composition were made from the Atmospheric Monitoring Station (AMS), $150 \mathrm{~m}$ south-southeast of AMOS-1.

KSG subtends a $60^{\circ}$ arc $\left(355-55^{\circ}\right)$ of influence on the AMS (Fig. 2b) and this sector is routinely excluded from atmospheric composition observations. However, since topography of the order of 600-700 $\mathrm{m}$ a.s.l. lies within this sector (Jiahong et al., 1998), flow in the marine boundary layer is often blocked and these wind directions are rarely observed in practice.

Mean monthly estimates of the mixing depth at KSG, obtained from the PC version of HYSPLIT v4.0 (HYbrid Single-Particle Lagrangian Integrated Trajectory; Draxler and Rolph, 2003), varied from 440 to $610 \mathrm{~m}(\sigma / \mu=44 \%)$. These calculations were based on meteorological data of $1^{\circ} \times 1^{\circ}$ resolution generated by the global data assimilation system (GDAS) model run by the National Weather Service's (NWS) National Centre for Environmental Prediction (NCEP). However, the tendency for HYSPLIT to overestimate mixing depths (e.g. Fig. 3, Lin et al., 2003) should be noted.

\subsection{Radon measurements}

Radon is a naturally occurring, radioactive gas, emitted by most soil and rocks. A noble gas, and poorly soluble, its primary atmospheric sink is radioactive decay (half-life, $t_{0.5}=$ 3.82 days). Since radon's oceanic sources are 2 orders of magnitude smaller than its terrestrial sources (Zahorowski et al., 2013), and its atmospheric lifetime is comparable to that of short-lived anthropogenic pollutants (e.g. $\mathrm{NO}_{\mathrm{x}}$ or $\mathrm{SO}_{2}$ ), the residence times of water and aerosols, and the timescale of many important aspects of atmospheric dynamics, radon is an ideal tracer for transport studies focusing on distant terrestrial pollution.

A $1500 \mathrm{~L}$ two-filter dual-flow-loop radon detector (Whittlestone and Zahorowski, 1998; Chambers et al., 2011) was installed within the Geophysics Building of KSG, 65 m east of AMOS-1. Air was sampled at $50 \mathrm{~L} \mathrm{~min}^{-1}$ through $50 \mathrm{~mm}$ high-density polyethylene (HDPE) agricultural pipe from $6 \mathrm{~m}$ above ground level (a.g.l.). The inlet was heated to $\sim 5^{\circ} \mathrm{C}$ to minimise snow/ice blockages, and a $400 \mathrm{~L}$ delay volume was used to prevent thoron $\left({ }^{220} \mathrm{Rn} ; t_{0.5}=55.6 \mathrm{~s}\right)$ contamination. The data recovery rate during the measurement period, accounting for calibrations, maintenance and technical difficulties, was $96 \%$.

The detector was calibrated monthly by injecting radon at $60 \mathrm{cc} \mathrm{min}^{-1}$ for $5 \mathrm{~h}$ from a Pylon Radium-226 source $(9.902 \pm 4 \% \mathrm{kBq})$ traceable to the National Institute of Standards and Technology (NIST) standards. The extensive oceanic fetch, small local flux (order of 0.077 atoms $\mathrm{cm}^{-2} \mathrm{~s}^{-1}$; Evangelista and Pereira, 2002; Solecki, 2005) and stability of the mixing depth on sub-synoptic timescales generally resulted in low radon concentrations with little diurnal variability. Consequently the ${ }^{226} \mathrm{Ra}$ source was sufficient to yield peaks 2 orders of magnitude greater than typical ambient concentrations. The detector's sensitivity (calibration factor) was determined to be $0.37 \mathrm{cts} \mathrm{s}^{-1} / \mathrm{Bq} \mathrm{m}^{-3}$ at the commencement of the measurements. This is expected to change very gradually with time, as a result of slow degradation of the alpha detection head assembly.

The instrumental background signal is attributable to the accumulation of the long-lived particulate radon progeny ${ }^{210} \mathrm{~Pb}\left(t_{0.5}=22.3\right.$ year $)$ on the detector's second filter, as well as cosmic radiation and various site-specific influences. Automatic background checks are performed 3-monthly intervals by shutting down the sampling and internal circulation blowers and subsequently monitoring the $30 \mathrm{~min}$ count rate for a period of $24 \mathrm{~h}$. Instrumental background at the commencement of measurements was determined to be around 

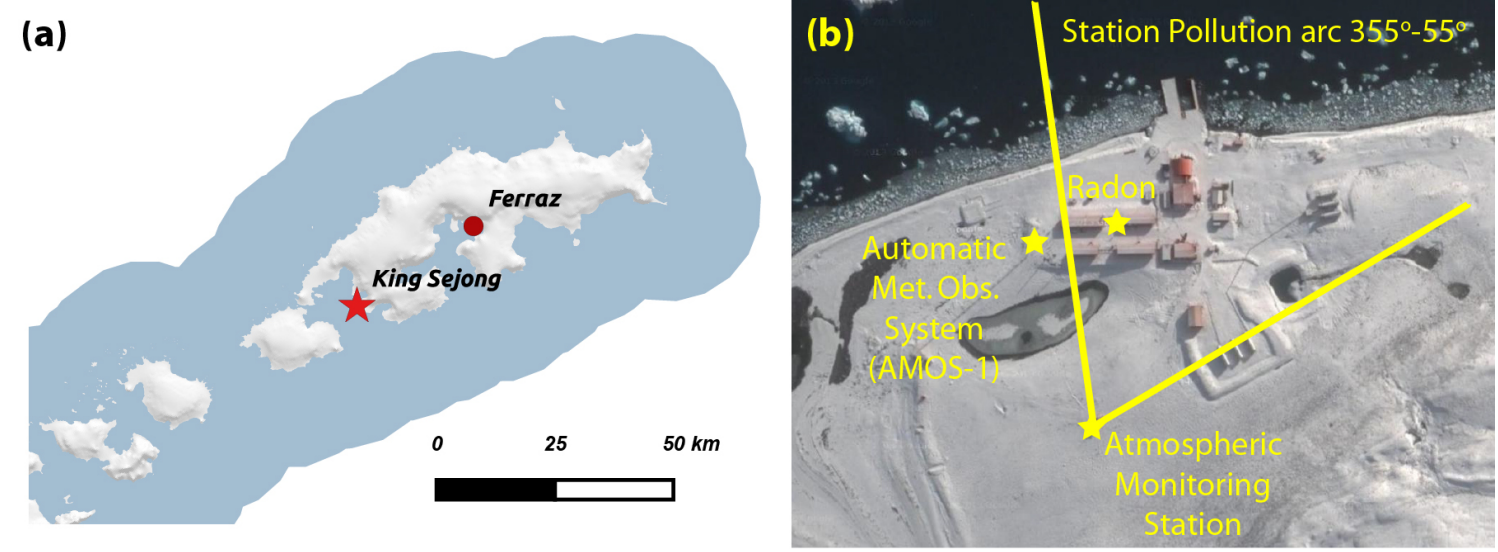

Figure 2. (a) Location of King Sejong Station on King George Island at the tip of the Antarctic Peninsula, and (b) the relative location of KSG radon observations, meteorological observations (automatic meteorological observation system \#1), the atmospheric monitoring station and the excluded station sector $\left(355-55^{\circ}\right)$.
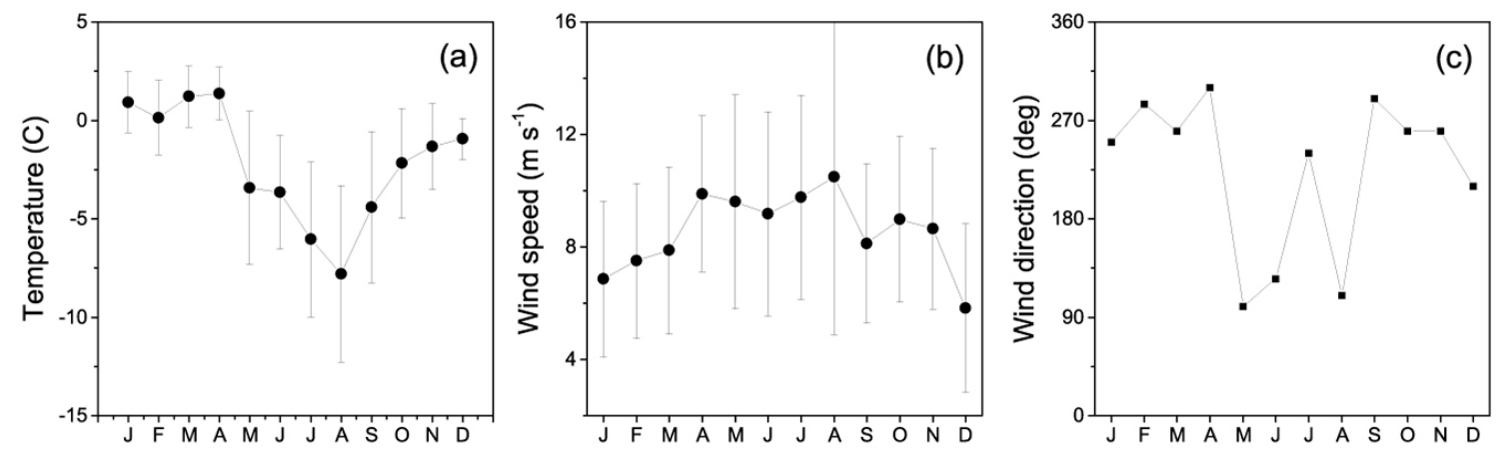

Figure 3. The 2013 Climate statistics for KSG: (a) mean monthly temperature, (b) mean monthly wind speed and (c) median monthly wind direction; whiskers represent $\pm 1 \sigma$ of hourly observations.

$34 \mathrm{cts}^{-1}$. While no significant change in background has thus far been observed (due to the low ambient radon levels), a gradual increase is anticipated as ${ }^{210} \mathrm{~Pb}$ accumulates on the detector's second filter.

Raw counts are integrated to hourly values before removing the background and calibrating to a radon concentration (in $\mathrm{mBq} \mathrm{m}^{-3}$ ). The standard deviation of the hourly background over the last $19 \mathrm{~h}$ of the $24 \mathrm{~h}$ background check is typically around $\sigma_{\mathrm{BG}}=6 \mathrm{ctsh}^{-1}$, which is equivalent to a radon concentration of about $5 \mathrm{mBqm}^{-3}$. Consequently, the removal of instrumental background may result in negative calibrated hourly radon values down to around $-10 \mathrm{mBq} \mathrm{m}^{-3}$ (i.e. $\left.-2 \sigma_{\mathrm{BG}}\right)$ when the actual atmospheric radon concentrations are very close to zero.

The relative counting error, $\mathrm{CE}_{\text {rel }}$, at a given photomultiplier voltage setting, $V$, is defined as

$\mathrm{CE}_{\text {rel }}(V)=\sigma_{\text {raw }} / C_{\text {net }}$,

where $\sigma_{\text {raw }}$ is the standard deviation of the raw hourly count produced in the presence of a constant radon concentration in the detector tank, and $C_{\text {net }}$ is the hourly count due to radon alone (i.e. with the instrumental background removed). Modelling $\sigma_{\text {raw }}$ assuming a linear composite Poisson process, $\mathrm{CE}_{\text {rel }}(V)$ can be estimated for a range of nominal ambient radon concentrations, $R_{\text {nom }}$, by recording the counts detected during the background $b(V)$ and calibration $\mathrm{c}(V)$ cycles as a function of the voltage setting:

$\mathrm{CE}_{\mathrm{rel}}(V)=\frac{\sqrt{k(c(V)-b(V))+b(V)}}{k(c(V)-b(V))}, k=\frac{R_{\mathrm{nom}}}{R_{\mathrm{cal}}}$,

where $R_{\text {cal }}$ is the (known) equilibrium radon concentration achieved within the detector tank during the calibration cycle. The detector's lower limit of detection (LLD), defined as the radon concentration at which the relative counting error first exceeds $30 \%$ at the chosen operating voltage, can then be determined from the resultant set of curves (Fig. 4). Based on the current operating voltage of $575 \mathrm{~V}$, the LLD of the KSG detector was determined by this method to be around $25 \mathrm{mBq} \mathrm{m}^{-3}$ for hourly integrations.

To put the measurement error in context, a $30 \%$ counting error at $25 \mathrm{mBq} \mathrm{m}^{-3}$ corresponds to a potential error in the concentration estimate of approximately $7 \mathrm{mBq} \mathrm{m}^{-3}$. 
Table 2. The 2013-2014 KSG monthly means, extremes and distributions $\left(10,25,50,75,90\right.$ percentiles) of atmospheric radon (mBq $\left.\mathrm{m}^{-3}\right)$.

\begin{tabular}{rrrrrrrrrrrr}
\hline Year & Month & Radon & SD & Min & 10th & 25th & 50th & 75th & 90th & Max & $N$ \\
\hline 2013 & Feb & 74.5 & 19.9 & 33.9 & 51.2 & 61.0 & 72.3 & 84.3 & 100.9 & 157.3 & 469 \\
2013 & Mar & 94.5 & 100.6 & 32.4 & 48.9 & 59.5 & 71.5 & 91.8 & 140.0 & 1053.9 & 643 \\
2013 & Apr & 118.9 & 194.4 & 30.9 & 48.2 & 56.5 & 67.8 & 82.1 & 164.1 & 1401.7 & 696 \\
2013 & May & 114.1 & 243.1 & 25.6 & 43.7 & 50.4 & 61.7 & 76.8 & 115.2 & 1901.5 & 733 \\
2013 & Jun & 71.9 & 92.9 & 20.3 & 38.4 & 45.2 & 55.7 & 68.5 & 86.6 & 1209.0 & 681 \\
2013 & Jul & 52.6 & 16.8 & 15.8 & 34.3 & 41.4 & 50.4 & 60.2 & 71.9 & 139.3 & 720 \\
2013 & Aug & 93.4 & 176.9 & 18.8 & 33.1 & 38.4 & 48.2 & 61.0 & 165.6 & 1586.1 & 733 \\
2013 & Sep & 83.4 & 123.6 & 16.6 & 30.9 & 37.6 & 45.9 & 61.7 & 101.6 & 819.8 & 682 \\
2013 & Oct & 68.1 & 56.5 & 15.8 & 33.9 & 41.4 & 52.7 & 72.3 & 111.4 & 584.2 & 733 \\
2013 & Nov & 52.0 & 37.6 & 12.0 & 28.6 & 35.4 & 44.4 & 55.7 & 68.5 & 426.1 & 708 \\
2013 & Dec & 46.9 & 16.8 & 15.1 & 30.1 & 36.9 & 44.4 & 53.4 & 66.2 & 171.6 & 705 \\
2014 & Jan & 52.9 & 15.7 & 16.6 & 34.6 & 42.2 & 51.2 & 61.7 & 73.8 & 137.0 & 733 \\
2014 & Feb & 60.5 & 15.6 & 23.3 & 45.2 & 51.2 & 58.0 & 67.8 & 77.5 & 192.7 & 661 \\
\hline
\end{tabular}

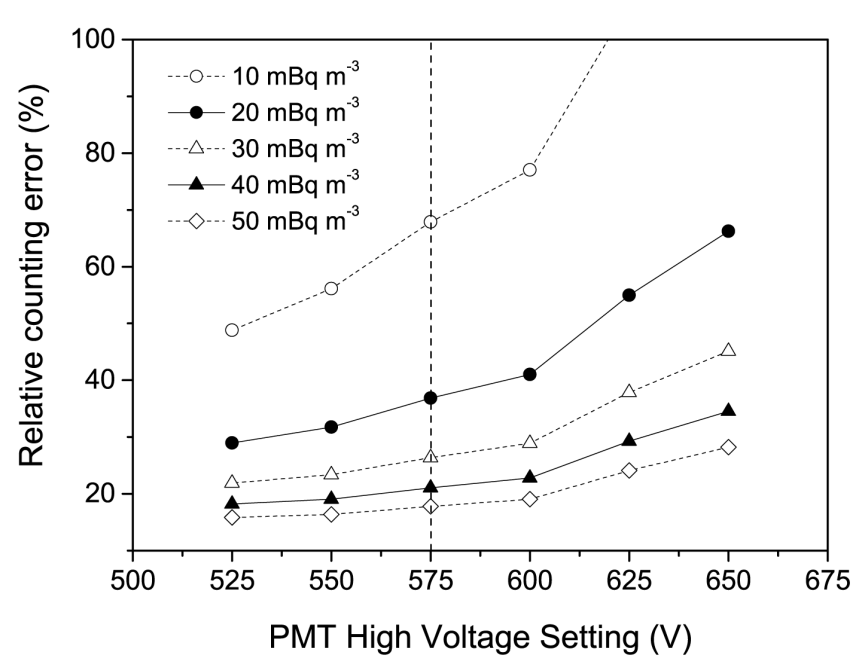

Figure 4. Relative counting error as a function of photomultiplier operating voltage for nominal radon concentrations between 10 and $50 \mathrm{mBq} \mathrm{m}^{-3}$. The KSG detector's current operating voltage is indicated with a vertical dashed line.

The relative uncertainty rapidly reduces with radon concentration such that the counting errors at $40 \mathrm{mBqm}^{-3}$ and $100 \mathrm{mBq} \mathrm{m}^{-3}$ are $17 \%$ and $9 \%$, respectively. Considered in conjunction with the standard deviation of monthly calibration estimates $(0.37 \pm \sigma 0.008 ; 2.2 \%)$, and the $\pm 4 \%$ accuracy of the calibration source, the typical measurement uncertainty for an hourly measurement of $100 \mathrm{mBq} \mathrm{m}^{-3}$ is $\sim 15 \mathrm{mBq} \mathrm{m}^{-3}$; but much less for longer-term averages. The relative error drops off as $\sim \mathrm{N}^{-1 / 2}$ for $\mathrm{N}$ data points.

\section{Results}

This section summarises the main characteristics of hourly KSG radon observations for the first year of operation. All times are local (GMT $-4 \mathrm{~h}$ ), and the Southern Hemisphere seasonal convention is used.

\subsection{Seasonal and diurnal variability}

The seasonal KSG radon cycle is characterised by a broad summer-autumn maximum and winter-spring minimum (Table 2; Fig. 5a). Median monthly radon concentrations decreased from $72 \mathrm{mBqm}^{-3}$ in February to $44 \mathrm{mBqm}^{-3}$ in November, with corresponding 10th percentiles (representing the least terrestrially influenced air), reducing from $49 \mathrm{mBq} \mathrm{m}^{-3}$ to $29 \mathrm{mBq} \mathrm{m}^{-3}$. The latter range is similar although opposite in phase - to the seasonal variability in Southern Ocean baseline air masses as observed at Cape Grim in Tasmania (27 to $44 \mathrm{mBq} \mathrm{m}^{-3}$; Zahorowski et al., 2013), where "baseline" here represents the least terrestrially perturbed air. Monthly 90th percentile concentrations were highly variable due to the station's proximity to South America $(\sim 900 \mathrm{~km})$, from which passing weather systems occasionally bring terrestrially influenced air to KSG year round (Fig. 5a).

Only in the 90th percentiles of the diurnal radon composite (Fig. 5b) was a weak diurnal signal recognisable, characterised by lower concentrations between 11 and $16 \mathrm{~h}$, and maximum concentrations between 2 and $6 \mathrm{~h}$. These values typically corresponded to periods of lower wind speed when local influences were more pronounced. The lack of a discernible diurnal cycle in the median values indicates that diurnal changes in mixing depth were minimal at KSG, and that mixing depth was more strongly influenced by changing synoptic weather patterns than the diurnal cycle of incident radiation. This behaviour is typical of island sites with a strong marine influence.

\subsection{Effects of local sources}

On average, local radon sources had little impact on KSG observations. Sector analyses (not shown) indicated a 52 

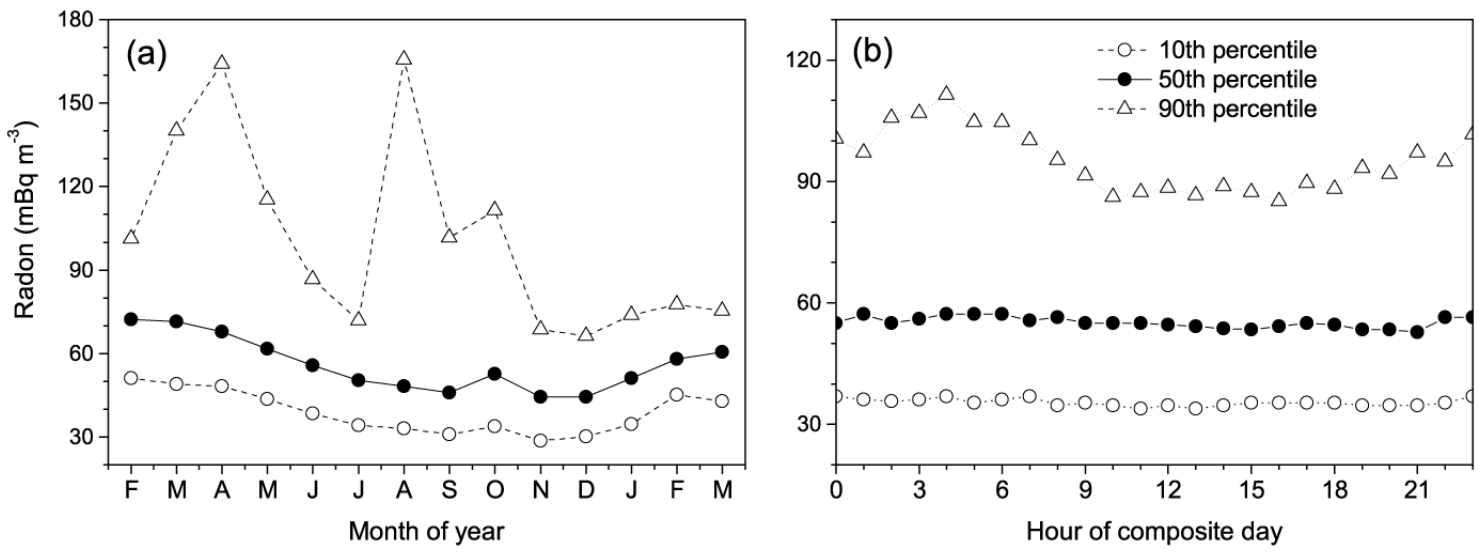

Figure 5. (a) Monthly distributions (10th, 50th and 90th percentiles) of hourly radon concentration, and (b) hourly distributions of composite diurnal values at KSG from February to October, 2013.

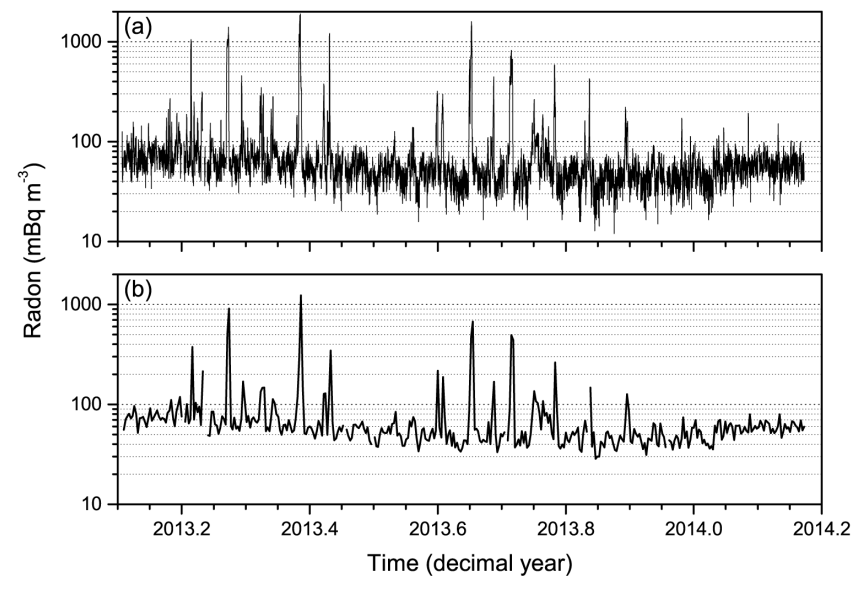

Figure 6. (a) Hourly and (b) daily-mean radon concentrations at King Sejong station. Note logarithmic scale.

(summer), 32 (autumn), 18 (winter) and 6 (spring) $\mathrm{mBq} \mathrm{m}^{-3}$ enhancement of median radon concentrations, above an assumed marine baseline value of $30 \mathrm{mBq} \mathrm{m}^{-3}$, from the $\mathrm{NE}$ and SW sectors (the main axis of the South Shetland Islands) in the current data set; the maximum value (in summer) was a factor of 3 to 4 less than the enhancement from directly north or south representing, respectively, South American air masses moving south and terrestrially effected tropospheric air subsiding near the pole and travelling north.

Evangelista and Pereira (2002) estimated that $<10 \%$ of the South Shetland Islands are free of ice, and that their effective mean radon flux is around 0.077 atoms $\mathrm{cm}^{-2} \mathrm{~s}^{-1}$. Based on this mean flux, together with approximate land fetches for the islands SW/NW of KSG of $100 \mathrm{~km} / 70 \mathrm{~km}$, HYSPLIT mixing depths in the range $440-610 \mathrm{~m}$ and a mean wind speed of $8 \mathrm{~m} \mathrm{~s}^{-1}$ (Fig. 3b), we estimate that the South Shetland Islands could enhance radon concentrations by around $33-46 \mathrm{mBq} \mathrm{m}^{-3}$ above oceanic baseline values. Bearing in mind the tendency for HYSPLIT to overestimate mixing depths, this compares closely with the summertime enhancements observed in the SW and NE sectors. Based on the observed radon enhancements in winter and spring, the mean radon emanation from the Shetland Islands when snow/ice covered might drop as low as $0.01-0.03$ atoms $\mathrm{cm}^{-2} \mathrm{~s}^{-1}$.

\subsection{Radonic storms}

Hourly and daily mean time series of KSG radon concentrations for the year of observations are presented in Fig. 6a and b, respectively. Days for which more than six of the potential 24 hourly measurements were not available were excluded from the daily mean plot.

A number of large positive anomalies are evident from the seasonal trend in radon concentration (Fig. 6; note logarithmic scale), some characterised by hourly concentrations $>1000 \mathrm{mBq} \mathrm{m}^{-3}$, others in the range $150-400 \mathrm{mBq} \mathrm{m}^{-3}$. Such events, widely reported throughout the network of Antarctic stations, are referred to as "radonic storms" (e.g. Ui et al., 1998; Wyputta, 1997; Pereira, 1990; Balkanski and Jacob, 1990; Polian et al., 1986; Lambert et al., 1970), and are understood to represent either the rapid transport of air from an "upstream" continent within a synoptic system (in the boundary layer), or an accumulation/release of locally sourced radon. Fetch regions associated with these "radonic storms" at KSG, as well as those associated with persistent low radon events, corresponding to the most aged Southern Ocean air masses, are investigated below.

\subsection{Fetch analysis}

This section characterises the predominant fetch regions of three kinds of KSG air masses:

1. high-radon events (hourly concentrations $>400 \mathrm{mBq}$ $\mathrm{m}^{-3}$ ); 

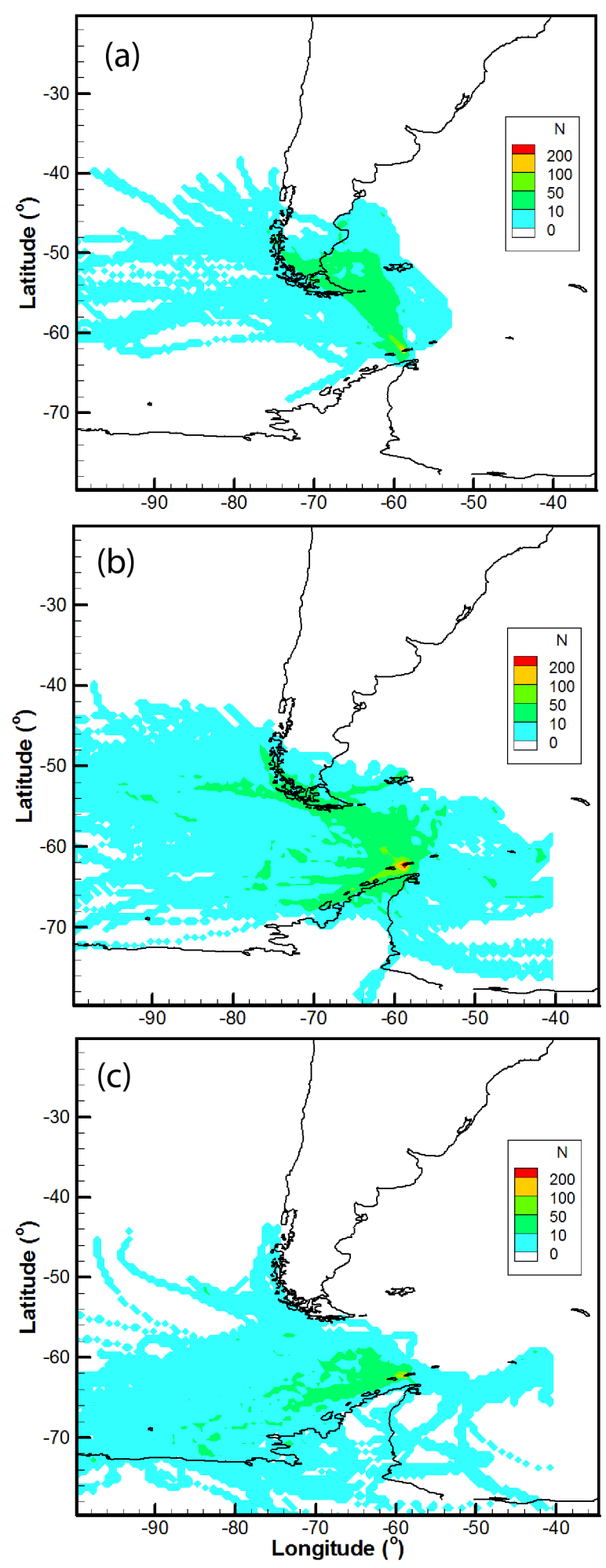

Figure 7. Trajectory density plots of (a) high-radon events $\left(>400 \mathrm{mBqm}^{-3}\right)$, (b) intermediate radon events (100$400 \mathrm{mBq} \mathrm{m}^{-3}$ ) and (c) least terrestrially perturbed events. Here " $\mathrm{N}$ " represents the number of times a trajectory passes through a $0.5^{\circ} \times 0.5^{\circ}$ grid cell.
2. intermediate events (hourly concentrations 100$\left.400 \mathrm{mBq} \mathrm{m}^{-3}\right)$

3. least perturbed air (persistent low radon events, where observed concentrations drop below the monthly first quartile value for at least 3 consecutive hours).

In subsequent applications of KSG radon observations, it is likely that each of these three air mass types would exhibit markedly different anthropogenic pollution signatures.

Figure $7 \mathrm{a}$ presents a trajectory density plot derived from HYSPLIT back trajectories corresponding to high-radon concentrations ( $>400 \mathrm{mBq} \mathrm{m}^{-3}$ ). While Pereira et al. (2006) reported transport to Ferraz from as far north as Brazil (with radon $>2000 \mathrm{mBq} \mathrm{m}^{-3}$ ), KSG high-radon events in 2013 were typically the result of slow-moving air masses crossing South America between 47 and $55^{\circ} \mathrm{S}$. In terms of potential anthropogenic pollutant sources, this fetch region includes several population centres of small-to-intermediate size, including Punta Arenas (population ca. 123000). Based on the findings of Pereira et al. (2006), considerable inter-annual variability in trace-gas emissions (e.g. $\mathrm{CO}$ and $\mathrm{CO}_{2}$ ) is likely for this fetch region.

A similar density plot for the intermediate events (100$400 \mathrm{mBq} \mathrm{m}^{-3}$ ), shown in Fig. $7 \mathrm{~b}$, indicated that these tended to be associated with local emissions from the islands around KSG (as also noted by Pereira, 1990, and Pereira et al., 2006) and the southernmost islands of South America. Another source of these events was fast-moving air masses from deep in the South Pacific. While their origins could not be traced to land by the available 10-day back trajectories, these air masses are thought to have originated from Australia or New Zealand (8-10 $000 \mathrm{~km}$ distant). While the existence of such events has not previously been noted in published Ferraz data sets, according to Heimann et al. (1990) the transport of distinct radon plumes over such distances is not uncommon. This has important implications for the potential transport of aged anthropogenic pollutants to the Antarctic Peninsula. If undiluted, a representative Australian radon event $\left(2500 \mathrm{mBq} \mathrm{m}^{-3}\right)$ would decay to activities between 150 and $400 \mathrm{mBq} \mathrm{m}^{-3}$ in $10-15$ days (see Sect. 4.3).

The density plot corresponding to the least terrestrially perturbed KSG air masses (Fig. 7c) identified either air masses moving slowly through the South Pacific within the marine boundary layer, or faster moving air masses that had recently crossed the coast of mainland Antarctica, but at elevations of $1-2 \mathrm{~km}$, which would likely be above the boundary layer (lower troposphere) at those locations. 

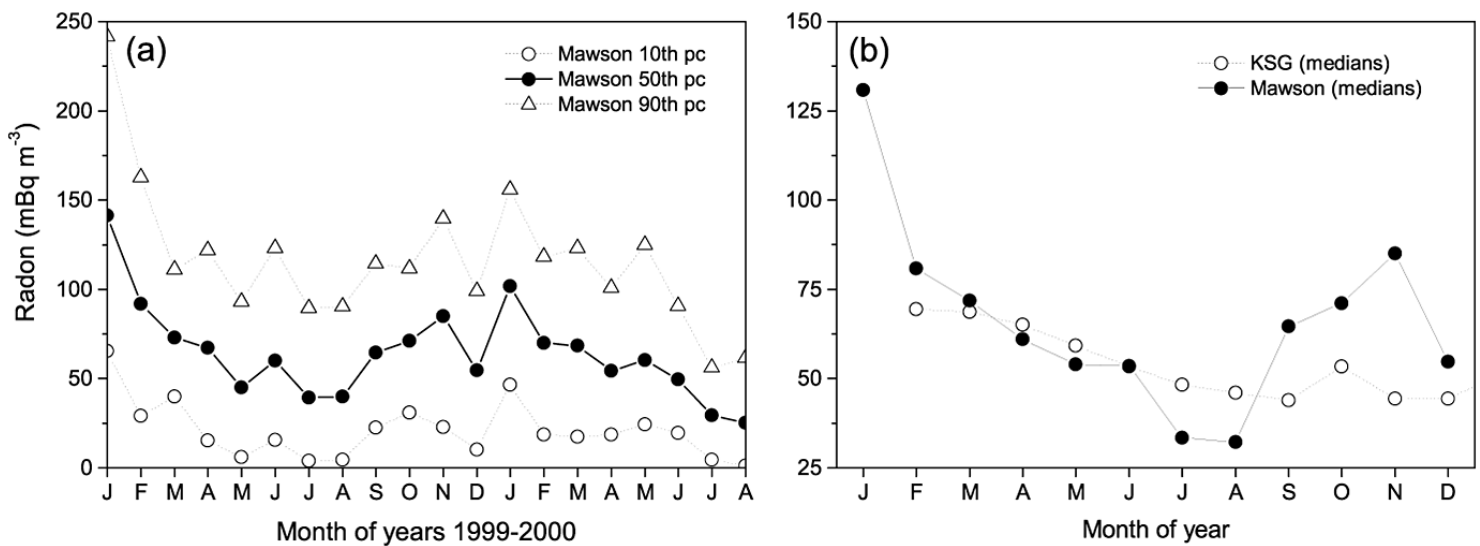

Figure 8. (a) Monthly distributions of adjusted hourly Mawson radon concentrations, and (b) comparison of median monthly radon concentrations between KSG and the adjusted Mawson data set (1999-2000 composite year).

\section{Discussion}

\subsection{Comparisons with previously reported Antarctic radon studies}

This section presents the KSG data to date in the context of existing Antarctic radon observations (Fig. 1), both to give credence to the developing data set, as well as to assist in our interpretation of the observed variability.

\subsubsection{Direct radon observations: two-filter detection method}

Prior to this study, the only other two-filter radon measurements in Antarctica were at Mawson Station between January 1999 and August 2000 (Whittlestone and Zahorowski, 2000; available at http://gcmd.nasa.gov/KeywordSearch/ Home.do?Portal=amd $\{\backslash \&\}$ MetadataType $=0$ ). While the Mawson detector's sensitivity was stable over the measurement period, instrumental background determination was problematic, likely attributable to local thoron $\left({ }^{220} \mathrm{Rn}\right)$ contamination since no thoron delay volume was used. Local thoron levels can sometimes be significant at Antarctic stations (e.g. Tositti et al., 2002). We corrected the Mawson radon record by first removing a linear trend in the instrumental background signal and then shifting the net hourly counts such that the monthly third percentile value was not less than $-2 \sigma_{\mathrm{BG}}$ (see Sect. 2.2). This required an assumption that the Mawson detector had a similar $\sigma_{\mathrm{BG}}$ to the current KSG detector as the two detectors are similar in design and construction.

Monthly distributions of the adjusted Mawson radon concentrations are shown in Fig. 8a. The representativeness of the Mawson observations in January and December is uncertain due to low data availability (not shown). However, the high January concentrations are consistent with summertime observations at the nearby Syowa Station (Ui et al., 1998 ) in the range $150-270 \mathrm{mBq} \mathrm{m}^{-3}$. In late winter (July-
August), median values are $25-39 \mathrm{mBq} \mathrm{m}^{-3}$, similar to the oceanic baseline values observed at Cape Grim (Zahorowski et al., 2013), and corresponding 10th percentile values are $1-3 \mathrm{mBq} \mathrm{m}^{-3}$.

Monthly medians for the 1999-2000 composite year at Mawson compare well with the 2013 KSG observations (Fig. 8b). Both stations show a seasonal cycle characterised by high summer and low winter concentrations that is typical of Antarctic sites (see also Fig. 9). Between March and June there is a particularly close correspondence between the two stations. In late winter, however, the data indicates that Mawson air masses are considerably more aged (with respect to remote terrestrial influences) than at KSG.

Overall, the mean February-to-February radon concentrations at KSG and Mawson Station were $77 \pm \sigma 100 \mathrm{mBq} \mathrm{m}^{-3}$ and $64 \pm \sigma 33 \mathrm{mBq} \mathrm{m}^{-3}$, respectively. Given the considerable interannual variability in mean annual radon concentrations of Antarctic stations, this $13 \mathrm{mBq} \mathrm{m}^{-3}$ difference is not particularly significant, but could easily be attributed to a combination of the proximity of KSG to South America, the 5.5 difference in latitude between the stations, and the presence of inter-annual variability.

\subsubsection{Direct radon observations: electrostatic precipitation method}

While numerous electrostatic precipitation radon measurements have been conducted in Antarctica (e.g. Pereira, 1990; Pereira et al., 2004, 2006; Ui et al., 1998; Tositti et al., 2002), little information on seasonal cycles has been published.

Pereira (1990) reports on two years of observations (19861987; excluding summers) at Ferraz Station, $30 \mathrm{~km} \mathrm{NE}$ of KSG. Mean concentrations reported for these periods $\left(26 \pm 18 \mathrm{mBq} \mathrm{m}^{-3}\right.$ and $\left.14 \pm 8 \mathrm{mBq} \mathrm{m}^{-3}\right)$, were considerably lower than our $2013 \mathrm{KSG}$ values $\left(76.5 \pm 100 \mathrm{mBq} \mathrm{m}^{-3}\right.$; see Table 2) and no seasonal cycle was apparent in the Ferraz data. The most extreme "radonic storms" reported 

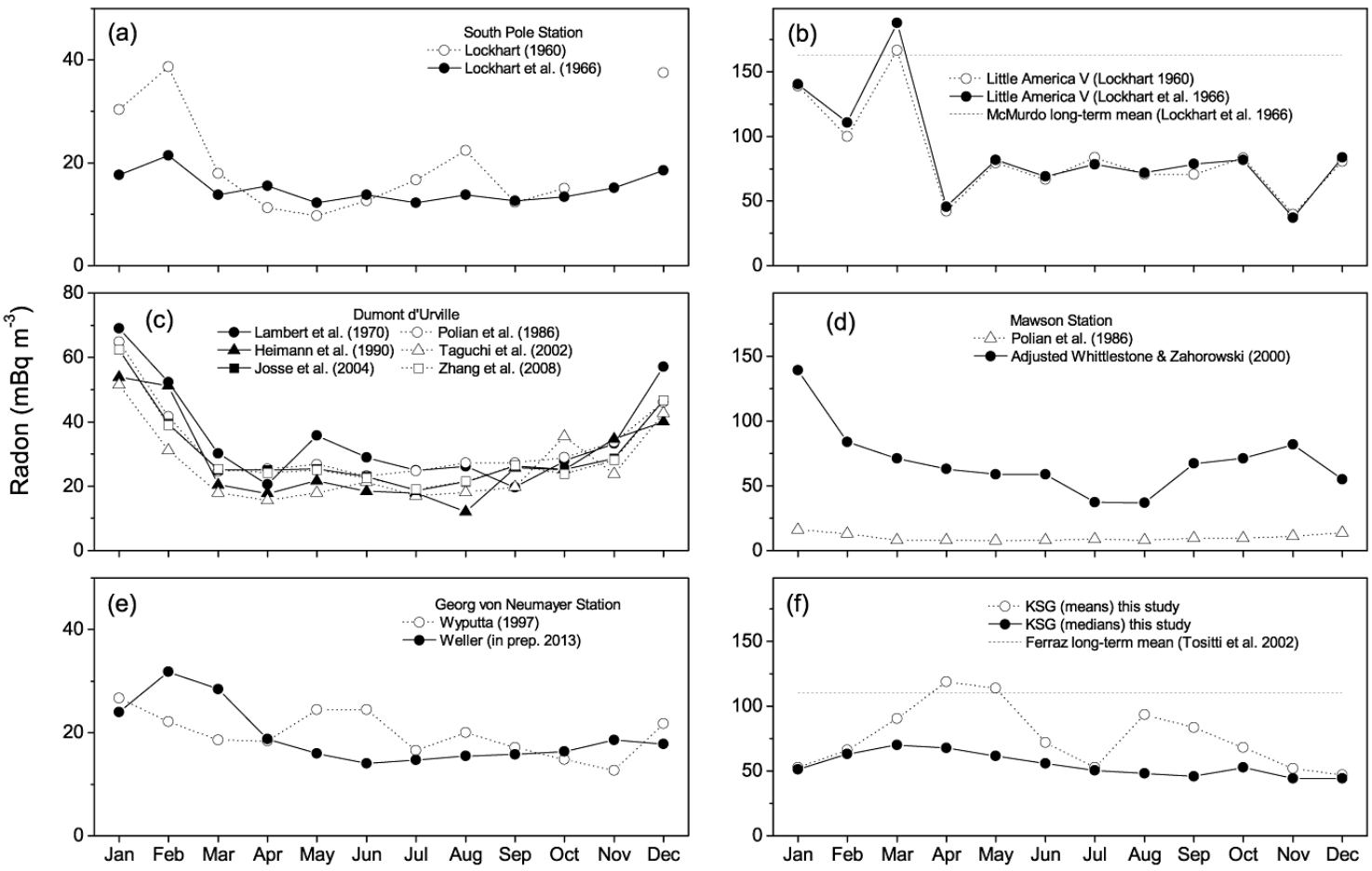

Month of composite year

Figure 9. Seasonal cycles of radon concentration in Antarctica observed using the indirect progeny method (a, b, $\mathbf{c}$ and e) and the direct two-filter method $(\mathbf{d}, \mathbf{f})$. Values are monthly means, unless otherwise stated. See Table 1 for measurement periods.

reached concentrations of $50-126 \mathrm{mBqm}^{-3}$, compared to $1000-1800 \mathrm{mBq} \mathrm{m}^{-3}$ in the present study (Fig. 6). In later publications, however, Pereira et al. $(2004,2006)$ refer to Ferraz radonic storms in June and October of 1997 reaching concentrations of $1300-2900 \mathrm{mBq} \mathrm{m}^{-3}$. Furthermore, in Table III of Tositti et al. (2002), mean annual Ferraz radon concentrations of $160 \pm 140 \mathrm{mBq} \mathrm{m}^{-3}$ and $156 \pm 144 \mathrm{mBq} \mathrm{m}^{-3}$ are reported for 1997 and 1998, respectively, and in Table IV a longer-term annual mean value of $110 \mathrm{mBq} \mathrm{m}^{-3}$ is stated. These results are an order of magnitude higher than the autumn-through-spring means of Pereira (1990), which may therefore be erroneous.

Ui et al. (1998) summarises five months (September 1996 to January 1997) of direct radon measurements at Syowa Station $\left(69^{\circ} \mathrm{S}, 39^{\circ} 35^{\prime} \mathrm{E}\right.$; see Fig. 1). Monthly averaged, daily mean radon concentrations varied from 150 to $270 \mathrm{mBq} \mathrm{m}^{-3}$. The high-ambient concentrations for this remote region were attributed to local emissions from exposed rock. Reported radonic storms reached concentrations of $1200 \mathrm{mBq} \mathrm{m}^{-3}$, comparable in magnitude to the KSG events, despite the nearest continental land fetch for Syowa being much more distant: $3800 \mathrm{~km}$ to Africa and $5000 \mathrm{~km}$ to South America.

Tositti et al. (2002) presented three summers of direct radon observations at Terra Nova Bay $\left(74.69^{\circ} \mathrm{S}\right.$, $164.12^{\circ} \mathrm{E}$ : see Fig. 1). The overall mean concentration $\left(510 \pm 430 \mathrm{mBq} \mathrm{m}^{-3}\right)$ was even higher than observed at
Syowa, and was attributed to local radon sources and shallow mixing depths (as evident from the pronounced diurnal cycle in radon concentrations observed at this site).

\subsubsection{Indirect radon observations: radon progeny technique}

The most commonly adopted technique for radon monitoring in Antarctic and sub-Antarctic regions is the indirect "progeny" technique (e.g. Lockhart, 1960; Lockhart et al., 1966; Lambert et al., 1970; Maenhaut et al., 1979; Polian et al., 1986; Heimann et al., 1990; Wyputta, 1997).

Seasonal radon cycles have been reported for numerous sites (Fig. 9), each characterised by maximum values in the warmer months (November through March), and minimum values in the colder months. Mean wind speeds are comparatively low in summer, and coastal sites experience the least snow/ice coverage. Site-to-site differences in these factors, as well as differences in mixing depth, contribute to the large variability in summertime radon maxima between sites (30$200 \mathrm{mBq} \mathrm{m}^{-3}$; Fig. 9). In winter, local source contributions are greatly reduced, and mean concentrations usually reflect well-aged or oceanic baseline values $\left(15-40 \mathrm{mBq} \mathrm{m}^{-3}\right)$. At some sites, however, shallow, stable boundary layers (or proximity to terrestrial sources, as is the case for KSG), can lead to winter mean radon concentrations higher than typical baseline values. 

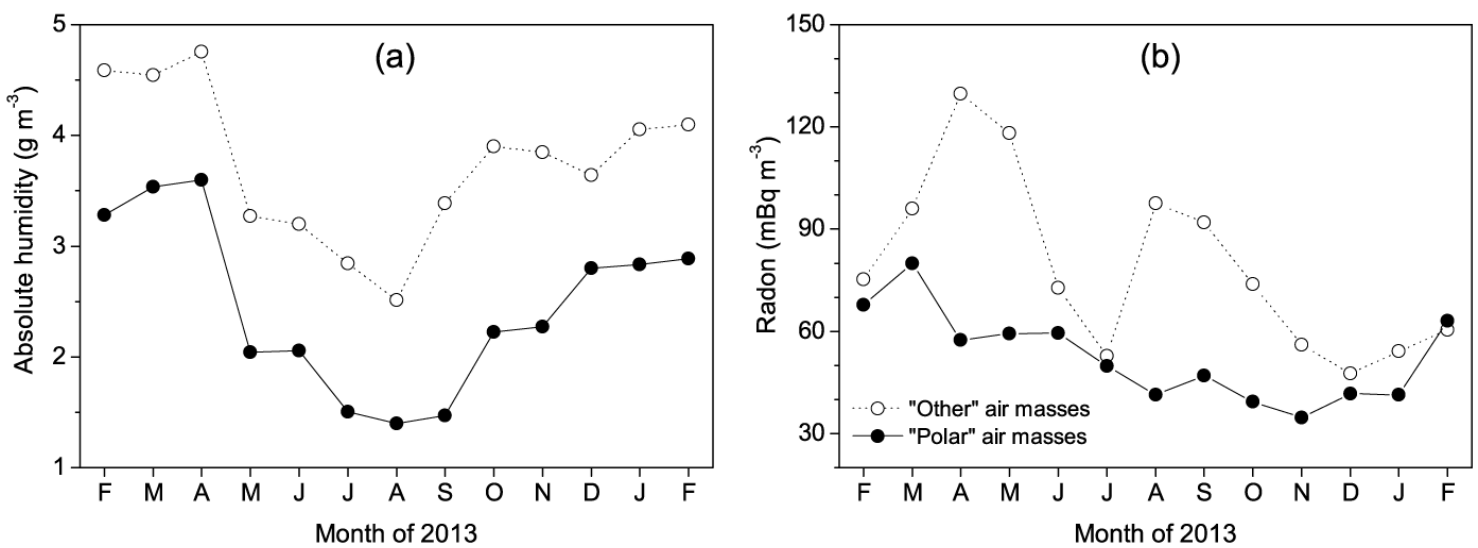

Figure 10. Comparison of monthly mean (a) absolute humidity and (b) radon concentration, between "polar" and other air masses.

Local radon sources at the permanently frozen South Pole station are virtually zero (Lockhart et al., 1966). The amplitude of the seasonal radon cycle at this site $\left(10-30 \mathrm{mBq} \mathrm{m}^{-3}\right.$; Fig. 9a) most likely reflects seasonal changes in the terrestrial radon signature of tropospheric air that is descending over the polar region. This matter is further discussed in Sect. 4.2.

The Wyputta (1997) Neumayer radon concentrations have been excluded from Fig. 9 due to reduced data quality in the pre-1995 data as described in Weller et al. (2013). In addition to problems discussed in Sect. 4.1.1, it should be noted that the Mawson station radon record reported by Polian et al. (1986) (open triangles, Fig. 9d) is inconsistent with other Antarctic radon observations - lower even than reported concentrations at South Pole - and may therefore be erroneous.

As well as the seasonal variability, inter-annual radon variability at Antarctic sites can also be significant; contributed to not only by changes in atmospheric circulation, but also sea ice extent (Weller et al., 2013). In all, 30-50\% variations in the annual mean and $30-70 \%$ variations in monthly means are not uncommon (e.g. Fig. 9c, Dumont d'Urville; and Weller et al., 2013, Neumayer).

\subsection{Sources of seasonal radon variability at Antarctic stations}

As shown in previous sections, despite the remoteness of most Antarctic coastal regions from significant terrestrial radon sources, mean concentrations well above oceanic baseline levels (27-44 $\mathrm{mBq} \mathrm{m}^{-3}$; Zahorowski et al., 2013) are frequently observed, particularly in summer. In addition to the influences of local radon sources and the direct transport of continental air masses to Antarctica within the boundary layer by passing synoptic weather systems (radonic storms), it has been hypothesised that indirect transport to polar regions through the mid- to upper-troposphere may play an important role in the seasonal radon variability (Heimann et al., 1990; Balkanski and Jacob, 1990; Polian et al., 1986; Hogan et al., 1982). Shortcomings in the representation of these large-scale transport patterns by weather and chemical transport models (which have long demonstrated an ability to transport "radonic storm" events to Antarctica) may explain their failure to successfully reproduce even the broad features (summer maximum, winter minimum) of the Antarctic seasonal radon cycle (Zhang et al., 2008, 2011; Josse et al., 2004; Taguchi et al., 2002; Heimann et al., 1990; Balkanski and Jacob, 1990). These shortcomings may be attributable to weaknesses in current parameterisations of moist convection and transport in the mid- to upper-troposphere.

Polian et al. (1986) report strong latitudinal gradients of radon and ${ }^{210} \mathrm{~Pb}$ activities from four summertime cruise transects between Cape Grim and Dumont d'Urville. Minimum activities were reported between 50 and $55^{\circ} \mathrm{S}$, where the mean Australian continental influence becomes minimal. South of this latitude, however, activities began to increase once more (see also Winkler et al., 1992; Lambert et al., 1990). While there is evidence of increasing oceanic radon flux densities in the Southern Ocean to latitudes of $\sim 55^{\circ} \mathrm{S}$ (e.g. summer observations of Zahorowski et al., 2013 and references therein), contributed to by increased zonal wind speeds and higher Radium-226 content in the surface waters, evidence of another mechanism is provided by the latitudinal gradient of fission products as reported by Polian et al. (1986). The activity of fission products, sourced from the upper atmosphere, also increased south of $55^{\circ} \mathrm{S}$, implying that large-scale circulation patterns (culminating in subsidence over the South Pole and subsequent northward flow to the Antarctic coastal regions), also play a role in the seasonal cycle of radon concentrations. Polian et al. (1986) hypothesised that air masses convected upwards over the southern portions of the Southern Hemisphere land masses reaches the mid- to upper-troposphere, travel south, subside in the polar region and then travel north to the Antarctic coastal regions. Balkanski and Jacob (1990) hypothesise that tropospheric injection of radon to the Southern Ocean atmosphere often exceeds that observed as radonic storms in the boundary layer. 


\subsubsection{Radon transport to KSG via polar subsidence}

In this section, we analyse radon in polar air masses to look for seasonality in the strength of continental influences on tropospheric air subsiding at the pole. Since wind direction alone is not always a clear indicator of long-term air mass fetch, we use a combination of back trajectories and air mass absolute humidity as an indicator of air most likely to have recently subsided over the pole and travelled north to KSG. Synoptic air masses that have spent a significant portion of their recent history within the marine boundary layer would contain more moisture than air masses having recently subsided from the upper atmosphere and travelled to KSG over a predominantly frozen fetch. For this analysis, we define "polar air masses" at KSG to be persistent events (more than 3 consecutive hourly samples) that have come from south of $70^{\circ} \mathrm{S}$ and have an absolute humidity below the 1 st quartile monthly value.

Mean monthly absolute humidity and radon concentrations of "polar" and "other" air masses at KSG are presented in Fig. 10. Polar air masses thus defined constituted, on average, $12 \%$ of all samples. A clear seasonality in the radon concentration of descending polar air masses at KSG is evident, characterised by a late summer maximum $\left(80 \mathrm{mBq} \mathrm{m}^{-3}\right)$ and a late winter minimum $\left(35 \mathrm{mBq} \mathrm{m}^{-3}\right)$. The 90 th percentile radon concentrations in February-March polar air masses reached $134 \mathrm{mBq} \mathrm{m}^{-3}$. Mean summer values are consistent with summer tropospheric $(\sim 3 \mathrm{~km})$ radon concentrations $\left(74 \mathrm{mBq} \mathrm{m}^{-3}\right)$ reported by Polian et al. (1986) over Dumont d'Urville.

These findings could be attributable to a stronger continental signature in the troposphere over Antarctica late in summer than in winter as a result of deep convection over the southern continents, and/or reduced tropospheric transport times/increased subsidence rates over the pole in summer than winter (e.g. Weller et al., 2002; Maenhaut et al., 1979). Briefly exploring these two possibilities, if seasonality in the continental signature reaching the troposphere (assuming a seasonally constant radon source function) was the sole factor, less than half $(\sim 45 \%)$ as much boundary layer air would need to be lofted/convected to the troposphere in winter than in summer. Alternatively, the observed seasonal change in polar air radon concentration would require tropospheric air masses to take $20-25 \%$ longer to reach the surface of Antarctica in winter than in summer. However, it should be noted that the observed amplitude $\left(45 \mathrm{mBq} \mathrm{m}^{-3}\right)$ of seasonality in "polar air" at KSG was larger than the amplitude of the seasonal radon cycle observed at the South Pole (10-30 $\mathrm{mBq} \mathrm{m}^{-3}$ : Fig. 9a), which we hypothesise to be driven by similar processes.

Regardless of the mechanism, a strong seasonally varying signature of remote terrestrial influences on tropospheric air masses descending at the pole is clearly evident in the KSG radon data set, and will presumably also be reflected in the concentrations/abundances of anthropogenic pollutants that are weakly soluble or less prone to washout.

\subsection{Estimating dilution factors for anthropogenic pollution events}

The composition of pollution events reaching KSG will be influenced by source strength, time of air mass contact with the source transit time, washout/deposition and dilution. Since most pollution has terrestrial origins, and the sole sink of radon is radioactive decay, analysing the radon concentration of terrestrial air masses provides a convenient means to estimate dilution of pollution plumes (e.g. Polian et al., 1986).

Here we choose the two events over the observation period with the strongest terrestrial signature as case studies for dilution estimates (Fig. 11a, b). Average back trajectories (Fig. 11c) were calculated for the periods indicated by red circles in Fig. 11a and b, from which the mean time over land, and transit time (from the South American coast to KSG), were estimated.

Event \#1: this air mass spent $27.5 \mathrm{~h}$ over land, with a mean elevation of $<1000 \mathrm{~m}$ a.g.l. (Fig. 11d), implying good contact with the surface. Assuming a radon flux of 1 atom $\mathrm{cm}^{-2} \mathrm{~s}^{-1}$ from the South American land surface (Zhang et al., 2011), 2062 $\mathrm{Bq} \mathrm{m}^{-2}$ of radon could have been accumulated in the moving air mass column. The transit time for this event was $60.5 \mathrm{~h}$, so after accounting for radioactive decay, the air mass' radon activity would be $1310 \mathrm{~Bq} \mathrm{~m}^{-3}$. If undiluted, the radon concentration at KSG would have been $4852 \mathrm{mBq} \mathrm{m}^{-3}$, based on the mean HYSPLIT mixing depth of $270 \mathrm{~m}$. Since the mean observed concentration was $1723 \mathrm{mBq} \mathrm{m}^{-3}$, we estimate a dilution factor of $\sim 2.8$, as a result of combined lateral dispersion and venting through the top of the boundary layer.

Event \#2: this air mass dropped to $\sim 1000 \mathrm{~m}$ when it crossed the coast, and spent $45.5 \mathrm{~h}$ over land, potentially accumulating $3412 \mathrm{~Bq} \mathrm{~m}^{-2}$ of radon in the column. After $42.5 \mathrm{~h}$ in transit, the activity would have been $\sim 2481 \mathrm{~Bq} \mathrm{~m}^{-2}$. Based on a mean mixing depth of $450 \mathrm{~m}$, the undiluted near-surface concentration would have been $5513 \mathrm{mBq} \mathrm{m}^{-3}$, compared to the observed value of $1363 \mathrm{mBq} \mathrm{m}^{-3}$. This equates to a dilution factor of 4.0 , which is larger than for event \#1, likely due to a frontal passage (indicated by the reversal of the trajectory path over South America).

These dilution factors are comparable to the values of $3-$ 7 estimated by Polian et al. (1986) for rapid continental air mass transport to sub-Antarctic stations in the Indian Ocean.

\section{Conclusions}

We report on the first year of hourly radon observations with a two-filter dual-flow-loop detector at King Sejong 

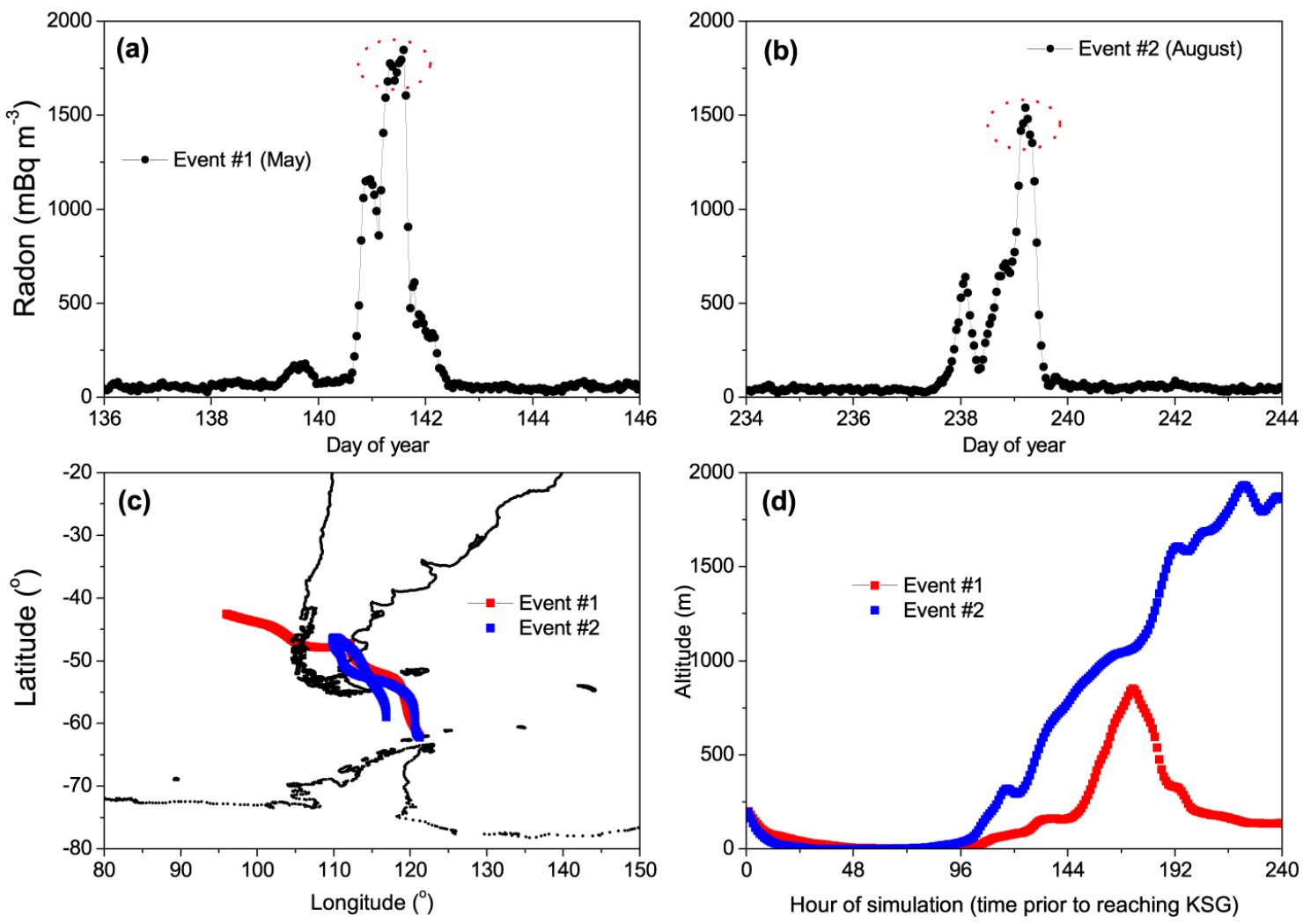

Figure 11. Summary of the largest two radon events of 2013: (a, b) hourly radon concentrations, (c) back-trajectory paths, and (d) elevation (ma.s.l.) of air mass along back trajectory (time in hours prior to air mass arrival at KSG).

station, Antarctic Peninsula. This detector was commissioned in February 2013 to supplement an ongoing trace-gas and aerosol monitoring program at the station. The set-up and operational characteristics of the detector, including calibration, instrumental background determination and lower limit of detection, are discussed in detail.

The seasonal cycle of radon at King Sejong station compared well with direct and indirect long-term radon measurements made at eight other Antarctic sites over the past 50 years. Our review of historic and ongoing radon measurements in this region identified flaws in some existing data sets, and resulted in an important revision of previously reported observations at Mawson Station.

A combination of back trajectory analyses and radon was used to identify fetch regions of terrestrially influenced air masses arriving at the Antarctic Peninsula, which included South America $\left(47-53^{\circ} \mathrm{S}\right)$, aged Australian plumes, and small local island influences. Plume dilution factors of 2.84.0 were estimated for the two largest advection events from South America.

A combination of air mass back-trajectories and absolute humidity was used to identify tropospheric air recently descended over the polar region. We identified and characterised a seasonality in the remote terrestrial influence on these polar air masses - understood to originate from con- vective activity over the Southern Hemisphere continents and plan to characterise similar trends in the physio-chemical properties of aerosols measured at King Sejong Station in future investigations.

Acknowledgements. This research was partly supported by KOPRI research grants PE14160 and PE14010. We thank the staff at King Sejong Station, King George Island, Antarctica, as well as Ot Sisoutham and Sylvester Werczynski at the Australian Nuclear Science and Technology Organisation for their support of the radon measurement program at King Sejong Station. We also acknowledge NOAA Air Resources Laboratory (ARL) who made available the HYSPLIT transport and dispersion model and the relevant input files for the generation of back trajectories used in this paper.

Edited by: Y. Balkanski 


\section{References}

Balkanski, Y. J. and Jacob, D. J.: Transport of continental air to the subantarctic Indian Ocean, Tellus B, 42, 62-75, 1990.

Berresheim, H. and Eisele, F. L.: Sulfur chemistry in the Antarctic Troposphere Experiment: An overview of project SCATE, J. Geophys. Res., 103, 1619-1627, 1998.

Chambers, S., Williams, A. G., Zahorowski, W., Griffiths, A. D., and Crawford, J.: Separating remote fetch and local mixing influences on vertical radon measurements in the lower atmosphere, Tellus B, 63, 843-859, 2011.

Crawford, J.H., Davis, D.D., Chen, G., Buhr, M., Oltmans, S., Weller, R., Mauldin, L., Eisele, F., Shetter, R., Lefer, B., Arimoto, R., and Hogan, A.: Evidence for photochemical production of ozone at the South Pole surface, Geophys. Res. Lett., 28, 3641-3644, 2001.

Davis, D., Nowak, J.B., Chen, G., Buhr, M., Arimoto, R., Hogan, A., Eisele, F., Mauldin, L., Tanner, D., Shetter, R., Lefer, B., and McMurry, P.: Unexpected High Levels of NO Observed at South Pole, Geophys. Res. Lett., 28, 3625-3628, 2001.

Davis, D., Chen, G., Buhr, M., Crawford, J., Lenschow, D., Lefer, B., Shetter, R., Eisele, F., Mauldin, L., and Hogan, A. South Pole NOx Chemistry: an assessment of factors controlling variability and absolute levels. Atmos. Environ., 38, 5375-5388, 2004.

Dentener, F., Feichter, J., and Jeuken, A.: Simulation of the transport of ${ }^{222} \mathrm{Rn}$ using on-line and off-line global models at different horizontal resolutions: a detailed comparison with measurements, Tellus B, 51, 573-602, 1999.

Draxler, R. R. and Rolph, G. D.: Hybrid Single-Particle Lagrangian Integrated Trajectory (HYSPLIT), model, http://www.arl.noaa. gov/ready/hysplit4.html, 2003.

Evangelista, H. and Pereira, E. B.: Radon flux at King George Island, Antarctic Peninsula, J. Environ. Radioact., 61, 283-304, 2002.

Gros, V., Martin, D., Poisson, N., Kanakidou, M., Bonsang, B., Le Guern, F., and Demont, E.: Ozone and C2-C5 hydrocarbon observations in the marine boundary layer between $45^{\circ} \mathrm{S}$ and $77^{\circ} \mathrm{S}$, Tellus B, 50, 430-448, 1998.

Heffernan, O.: Grim picture of polar ice-sheet loss, Nature, doi:10.1038/nature.2012.11921, 29 November 2012.

Heimann, M., Monfray, P., and Polian, G.: Modeling the long-range transport of ${ }^{222} \mathrm{Rn}$ to subantarctic and Antarctic areas, Tellus B, 42, 83-99, 1990.

Helmig, D., Oltmans, S. J., Carlson, D., Lamarque, J.-F., Jones, A., Labuschagne, C., Anlauf, K., and Hayden, K.: A review of surface ozone in the polar regions, Atmos. Environ., 41, 5138-5161, 2007.

Hogan, A., Barnard, S., Samson, J., and Winters, W.: The transport of heat, water vapour and particulate material to the South polar plateau, J. Geophys. Res., 87, 4287-4292, 1982.

Ilic, R., Rusov, V. D., Pavlovych, V. N., Vaschenko, V. M., Hanzic, L., and Bondarchuk, Y. A.: Radon in Antarctica, Radiat. Meas., 40, 415-422, 2005.

Jacobi, H.-W., Weller, R., Jones, A. E., Anderson, P. S., and Schrems, O.: Peroxyacetyl nitrate (PAN) concentrations in the Antarctic troposphere measured during the photochemical experiment at Neumayer (PEAN'99), Atmos. Environ., 34, 5235$5247,2000$.

Jiahong, W., Jiancheng, K., Jiankang, H., Zichu, X., Leibao, L., and Dali, W. Glaciological studies on the King George Island ice cap,
South Shetland Islands, Antarctica. Ann. Glaciol., 27, 105-109, 1998.

Jones, A. E., Wolff, E. W., Salmon, R. A., Bauguitte, S. J.-B., Roscoe, H. K., Anderson, P. S., Ames, D., Clemitshaw, K. C., Fleming, Z. L., Bloss, W. J., Heard, D. E., Lee, J. D., Read, K. A., Hamer, P., Shallcross, D. E., Jackson, A. V., Walker, S. L., Lewis, A. C., Mills, G. P., Plane, J. M. C., Saiz-Lopez, A., Sturges, W. T., and Worton, D. R.: Chemistry of the Antarctic Boundary Layer and the Interface with Snow: an overview of the CHABLIS campaign, Atmos. Chem. Phys., 8, 3789-3803, doi:10.5194/acp-8-3789-2008, 2008.

Josse, B., Simon, P., and Peuch, V.-H.: Radon global simulations with the multiscale chemistry and transport model MOCAGE, Tellus B, 56, 339-356, 2004.

Lambert, G., Polian, G., and Taupin, D.: Existence of periodicity in radon concentrations and in the large-scale circulation at lower altitudes between 40 and $70^{\circ}$ S, J. Geophys. Res., 75, 23412345, 1970.

Lambert G., Le Roulley J.-C., and Kritz M.: Box model for radon transfers into the stratosphere, Tellus B, 42, 135-141, 1990.

Lee, B. Y., Kwon, T. Y., Lee, J. S., and Won, Y. I.: Surface air temperature variations around the Antarctic peninsula: Comparison of the west and east sides of the peninsula, Oc. Pol. Res., 24, 267-278, 2002.

Lin, J. C., Gerbig, C., Wofsy, S. C., Andrews, A. E., Daube, B. C., Davis, K. J., and Grainger, C. A.: A near-field tool for simulating the upstream influence of atmospheric observations: The Stochastic Time-Inverted Lagrangian Transport (STILT) model, J. Geophys. Res., 108, 4493, doi:10.1029/2002JD003161, 2003.

Lockhart, L. B.: Atmospheric radioactivity in South America and Antarctica, J. Geophys. Res., 65, 3999-4005, 1960.

Lockhart, L. B., Patterson, R. L., and Saunders, A. W.: Airborne radioactivity in Antarctica, J. Geophys. Res., 71, 1985-1991, 1966.

Maenhaut, W., Zoller, W. H., and Coles, D. G.: Radionuclides in the South Pole atmosphere. J. Geophys. Res., 84, 3131-3138, 1979.

Murphey, B. B. and Hogan, A. W.: Meteorological transport of continental soot to Antarctica?, Geophys. Res. Lett., 19, 33-36, 1992.

Oncley, S. P., Buhr, M., Lenschow, D. H., Davis, D., and Semmer, S. R.: Observations of summertime NO fluxes and boundary-layer height at the South Pole during ISCAT 2000 using scalar similarity, Atmos. Environ., 38, 5389-5398, 2004.

Pereira, E. B.: Radon-222 time series measurements in the Antarctic peninsula (1986-1987), Tellus B, 42, 39-45, 1990.

Pereira, E. B., Evangelista, H., Pereira, K. C. D., Cavalcanti, I. F. A., and Setzer, A. W.: Apportionment of black carbon in the South Shetland Islands, Antarctic Peninsula, J. Geophys. Res., 111, D03303, doi:03310.01029/02005JD006086, 2006.

Pereira, K. C. D., Evangelista, H., Pereira, E. B., Simoes, J. C., Johnson, E., and Melo, L. R.: Transport of crustal microparticles from Chilean Patagonia to the Antarctic Peninsula by SEM-EDS analysis, Tellus B, 56, 262-275, 2004.

Polian, G., Lambert, G., Ardouin, B., and Jegou, A.: Long-range transport of continental radon in subantarctic and Antarctic areas, Tellus B, 38, 178-189, 1986.

Solecki, A. T.: Radon and thoron daughter activities in the environment of the King George Island (West Antarctica), Ann. Geophys., 48, 129-133, 2005, http://www.ann-geophys.net/48/129/2005/. 
Steig, E. J. and Orsi, A. J.: The heat is on in Antarctica, Nat. Geosci., 6, 87-88, 2013.

Taguchi, S., Iida, T., and Moriizumi, J.: Evaluation of the atmospheric transport model NIRE-CTM-96 by using measured radon-222 concentrations, Tellus B, 54, 250-268, 2002.

Taguchi, S., Tasaka, S., Matsubara, M., Osada, K., Yokoi, T., and Yamanouchi, T.: Air-sea gas transfer rate for the Southern Ocean inferred from 222Rn concentrations in maritime air and a global atmospheric transport model, J. Geophys. Res., 118, 7606-7616, 2013.

Tositti, L., Pereira, E. B., Sandrini, S., Capra, D., Tubertini, O., and Bettoli, M. G.: Assessment of summer trends of tropospheric radon isotopes in a coastal Antarctic Station (Terra Nova Bay), Intern. J. Environ. Anal. Chem., 82, 259-274, 2002.

Ui, H., Tasaka, S., Hayashi, M., Osada, K., and Iwasaka, Y. Preliminary results from radon observations at Syowa station, Antarctica, during 1996, Polar Meteorol. Glaciol., 12, 112-123, 1998.

Wada, A., Murayama, S., Kondo, H., Matsueda, H., Sawa, Y., and Tsuboi, K.: Development of a Compact and Sensitive Electrostatic Radon-222 Measuring System for Use in Atmospheric Observation, J. Meteorol. Soc. Japan, 88, 123-134, 2010.

Weller, R., Jones, A. E., Wille, A., Jacobi, H.-W., McIntyre, H. P., Sturges, W. T., Huke, M., and Wagenbach, D.: Seasonality of reactive nitrogen oxides (NOy) at Neumayer Station, Antarctica, J. Geophys. Res., 107, 4673, doi:4610.1029/2002JD002495, 2002.

Weller, R., Levin, I., Schmithüsen, D., Nachbar, M., Asseng, J., and Wagenbach, D.: On the variability of atmospheric ${ }^{222} \mathrm{Rn}$ activity concentrations measured at Neumayer, coastal Antarctica, Atmos. Chem. Phys. Discuss., 13, 32817-32847, doi:10.5194/acpd-13-32817-2013, 2013.

Whittlestone, S. and Zahorowski, W.: Baseline radon detectors for shipboard use: Development and deployment in the First Aerosol Characterization Experiment (ACE 1), J. Geophys. Res., 103, 16743-16751, 1998.
Whittlestone, S. and Zahorowski, W.: Radon measurements at Mawson and Macquarie Island, CAASM Metadata, updated 2006, Australian Antarctic Data Centre, available online at: http: //data.aad.gov.au/aadc/portal/index.cfm?fileid=827, 2000.

Wilkniss, P. E., Larson, R. E., Bressan, D. J., and Steranka, J.: Atmospheric radon and continental dust near the Antarctic and their correlation with air mass trajectories computed from Nimbus 5 satellite photographs, J. Appl. Meteorol., 13, 512-515, 1974.

Winkler, P., Brylka, S., and Wagenbach, D.: Regular fluctuations of surface ozone at George-von-Neumayer station, Antarctica, Tellus B, 44, 33-40, 1992.

Wolff, E. W., Legrand, M. R., and Wagenbach, D.: Coastal Antarctic aerosol and snowfall chemistry. J. Geophys. Res., 103, 1092710934, 1998.

Wyputta, U.: On the transport of trace elements into Antarctica using measurements at the Georg-von-Neumayer station, Tellus B, 49, 93-111, 1997.

Zahorowski, W., Griffiths, A. D., Chambers, S. D., Williams, A. G., Law, R. M., Crawford, J., and Werczynski, S.: Constraining annual and seasonal radon-222 flux density from the Southern Ocean using radon-222 concentrations in the boundary layer at Cape Grim, Tellus B, 65, 19622, doi:10.13402/tellusb.v19665i19620.19622, 2013.

Zhang, K., Wan, H., Zhang, M., and Wang, B.: Evaluation of the atmospheric transport in a GCM using radon measurements: sensitivity to cumulus convection parameterization, Atmos. Chem. Phys., 8, 2811-2832, doi:10.5194/acp-8-2811-2008, 2008.

Zhang, K., Feichter, J., Kazil, J., Wan, H., Zhuo, W., Griffiths, A. D., Sartorius, H., Zahorowski, W., Ramonet, M., Schmidt, M., Yver, C., Neubert, R. E. M., and Brunke, E.-G.: Radon activity in the lower troposphere and its impact on ionization rate: a global estimate using different radon emissions, Atmos. Chem. Phys., 11, 7817-7838, doi:10.5194/acp-11-7817-2011, 2011. 